\title{
Postavení České republiky v institucionální struktuře Evropské unie
}

\author{
Analýza vývoje předpokládaného institucionálního zastoupení ČR \\ v EU od počátku procesu rozšiřování
}

\author{
Petr Fiala - Markéta Pitrová
}

Evropská unie (EU) představuje komplikovaný fenomén, který je nestandardním subjektem mezinárodních vztahů, a to jak z hlediska ekonomické, tak i politické integrace. Vznik Evropské unie na základě Smlouvy o Evropské unii, podepsané 7. února 1992, obohatil dosavadní Evropské společenství (ES) o dimenzi politické jednoty postavené na společné zahraniční a bezpečnostní politice (SZBP - tzv. 2. pilír) , o harmonizaci oblasti justice a vnitra (JaV - tzv. 3. pilíř) a konečně také o koncepci evropského občanství. Součástí Smlouvy o EU se stal rovněž přesný harmonogram Hospodářské a měnové unie (HMU), která se připojila k nadnárodně spravovaným oblastem, jako jsou společná obchodní politika, zemědělství, doprava a politika veřejné soutěže.

Toto jednoznačné a pro další desetiletí určující prohloubení integrace ${ }^{1}$ mělo vliv nejen na stávající členské země, ale výrazně ovlivnilo i státy usilující o vstup do Evropského společenství. Tato změna byla symbolicky vyjádřena konstatováním, že kandidáti již nevstupují do ekonomického seskupení s nadnárodními rysy, ale do politické unie, která aspiruje na společnou zahraniční a bezpečnostní politiku a prostor bez vnitřních hranic. V návaznosti na podpis nové smlouvy redefinovala nově založená EU podmínky pro přistoupení v podobě tzv. kodaňských kritérií (Kodaň 21.-22. června 1993). Transformací ES v EU, která byla opatřena určitými vstupními podmínkami, se význam rozhodnutí kandidátských států a mezi nimi i ČR žádat o členství zásadně zvýšil.

Předložený text analyzuje podmínky postavení kandidátských států, resp. ČR, po jejich vstupu do EU, jak se měnily v průběhu devadesátých let v návaznosti na revize smluvních dokumentů. Základním kritériem, které je zvoleno jako indikátor postavení, je předpokládané zastoupení ČR v klíčových institucích EU. Toto kritérium není zvoleno náhodně: na jedné straně je zastoupení národních států v evropských centrálních orgánech obecně považováno za základní východisko pro určení a hodnocení míry vlivu, které jednotlivé státy uvnitř EU mají, na straně druhé je pak právě kvalitativní a také kvantitativní stránka zastoupení podstatnou a do jisté míry měřitelnou součástí vyjednávání při procesu vstupu nových členských zemí. Základní výzkumnou otázkou, kterou v této souvislosti analyzujeme, je, zda v průbě-

Sociální studia. Fakulta sociálních studií Masarykovy univerzity v Brně, 1/2004. S. 75-92. ISSN 1212-265X. 
hu procesu rozšiřování docházelo ke změnám v předpokládaném postavení České republiky v institucionální struktuře EU a zda tyto změny z hlediska zastoupení posilovaly nebo naopak oslabovaly potenciální pozici ČR v rámci EU.

\section{Charakter evropských institucí, postavení členských zemí a změny v dưsledku prìpravovaného rozšiřování}

Instituce EU se vyznačují kompilačním charakterem odrážejícím prvky nadnárodního a mezivládního př́stupu ke sjednocení. Na straně jedné umožňují členům v určitých omezených oblastech obhajovat své zájmy i za použití práva veta a na straně druhé zde nalezneme takové prvky, jako je kontrola ze strany Evropského soudního dvora, který působí na základě principu př́mého účinku a nadřazenosti evropského práva (Fiala, Pitrová 2003: 349-351). Výrazným charakteristickým rysem EU je také permanentní vývoj evropských institucí, které neustále reagují na proměnu integračních cílů definovaných v závislosti na aktuálních ekonomických a zahraničněpolitických výzvách. Jejich opakovaná transformace je také ovlivněna zvyšujícím se počtem aktérů (států) v rozhodovacím procesu. Podstatnou charakteristikou EU je také provázanost institucionálního schématu, v němž není fakticky aplikován princip dělení moci (s výjimkou Evropského soudního dvora) a kde instituce působí ve vzájemné provázanosti (Pitrová 2002: 49-52).

Podstatnou funkcí institucionální struktury EU je zajištění komunikace mezi členskými státy a vytvoření mechanismů umožňujících přijímání rozhodnutí, a tím ve svém důsledku i rozvíjení integrace. Proces sjednocování je převážně postaven na supranacionálním principu a „nedovoluje“ revizi. Naopak se předpokládá, že zúčastnění aktéři jsou jednotlivými rozhodnutími „uzamčeni“ v systému bez možnosti návratu. Tyto skutečnosti vedou k tomu, že vyjednávací pozice jednotlivých zemí je velmi složitá a citlivá. Navíc spolu jednají aktéři, kteří vykazují zásadní rozdíly z hlediska rozlohy, velikosti populace či hospodářského nebo vojenského potenciálu.

Orgány společenství mají za úkol zajistit dostatečnou reprezentaci malých zemí a současně garantovat realizaci zájmů velkých členských států, které nejenže ve velké míře financují aktivity Unie, ale také reprezentují většinu jejího obyvatelstva. V prŕípadě každé vlny rozšíření musí být nalezen složitý kompromis při určení vlivu jednotlivých zemí v základním „institucionálním trojúhelníku“ (Rada, Evropský parlament, Komise). Je zř̌ejmé, že návrhy snižující vliv malých členských zemí jsou touto skupinou odmítány jako krok proti rovnosti všech členů Unie.

Při diskusích o zastoupení v klíčových orgánech EU se v centru pozornosti zpravidla ocitá proces vážení hlasů v Radě, ve které jsou malé členské státy tradičně nadhodnoceny. Rozšiřování společenství znamená ve většině případů právě přijímání malých států, a tudíž i zvýšené ohrožení velkých zemí. ${ }^{2}$ Ty se samozřejmě snaží o zachování dostatečného vlivu, jenž by jim zajistil kontrolu nad vynakládanými finančními prostředky do rozpočtu Unie. Proto je s každým dalším rozšířením stále komplikovanější určení prahu kvalifikované většiny (tradičně okolo $71 \%$ hlasů), definování podmínek působení blokační menšiny ${ }^{3}$ a zodpovězení otázky, zda je rozhodování kvalifikovanou většinou skutečně odpovídajícím způsobem rozhodování, nebo zda by nemělo být nahrazeno jiným modelem. Kvalifikovaná většina posiluje supranacionální charakter Unie a zajišt’uje flexibilnější postup v rozhodovacím procesu, ale 
současně znemožňuje členům dostatečně efektivní obranu jejich zájmů. Opakovaně tedy musí být hledána politická odpověd' na otázku, zda je řešením aplikace kvalifikované většiny za současného použití spolurozhodovacího postupu v Evropském parlamentu, nebo zda mají být zachovány body, v nichž bude státům přiznáváno právo veta bez ohledu na komplikace a zpomalení integračního procesu, které to může vyvolat (Sherrington 2000: 175-179).

Boj o vliv v Radě se projevuje také v Evropském parlamentu, který ačkoliv je ve srovnání s Radou svým vlivem na rozhodovací procesy mnohem slabší, představuje významnou platformu pro prosazování zájmů. V průběhu integračního vývoje se však opakovaně aplikované navyšování mandátů o nově vstupující státy v souvislosti s realizací jednotlivých vln rozšiřování nezdá být ideální alternativou stejně jako navyšování počtu reprezentantů v poradních orgánech, Evropském soudním dvoře, nebo Dvoře auditorů.

Problém spojený s možností hájit adekvátně národní zájmy v evropských institucích se nevyhýbá ani Komisi, která má ve smlouvách úkol vystupovat nadnárodně bez ohledu na zájmy členských zemí. Realita spojená s působením Komise ale ukazuje, že komisaři jsou spíše než členové nadnárodního týmu jakýmisi „bránami“ pro působení zájmových skupin a fungují jako informační kanály pro třetí strany včetně národních vlád (Mazey, Richardson 1994: 169-188). Nárůst počtu členských zemí proto nevyvolává pouze diskusi o akceschopnosti úřadu a logickém členění resortů při permanentním zvyšování počtu komisařu, ale je také - nebo především - otázkou rovnosti přístupu členských států do Komise. Z hlediska požadavku rovného zastoupení v „nadnárodním“ orgánu je doposud ustálená favorizace velkých členských zemí ${ }^{4}$, které měly dva členy v Komisi, nadále neudržitelná.

Postavení členských zemí je v rámci tohoto systému dané celkovou pozicí státu v základním trojúhelníku. Určit mocenský vliv konkrétní země je možné až po souhrnném zhodnocení počtu hlasů v Radě, mandátů v Evropském parlamentu a křesel v Komisi s přihlédnutím k pravidlům rozhodovacího mechanismu. Veškeré tyto proměnné prošly po roce 1993 velkými změnami. Během tohoto reformního období se pozice členských států intenzivně proměňovala a v závislosti na tom se také zásadně měnily podmínky pro kandidátské země. V této souvislosti se objevuje několik otázek, s nimiž byly v průběhu dlouhého přistupovacího procesu kandidátské země včetně České republiky postupně konfrontovány: Do jaké míry se proces revize evropských institucí dotkl žadatelů o členství? Bylo pro ně celkové prodloužení př́ístupového procesu př́nosem, nebo naopak nevýhodou? Jaké byly možnosti ČR v rámci jednotlivých smluvních novelizací? Je pozice ČR v př́stupové smlouvě taková, aby odpovídala požadavkům na efektivní reprezentaci národních zájmů? Nebo by tuto potřebu splňovala lépe struktura předpokládaná evropskou ústavou, která byla členskými státy odmítnuta?

\section{Institucionální model EU po prijietí Amsterodamské smlouvy a předpokládaná pozice ČR}

Amsterodamská smlouva vznikla z prŕmého podnětu předchozího dokumentu, tedy jako realizace článku N Smlouvy o EU. Nikdy dř́ve nebyla novelizace smluv provedena na základě předem plánovaného a smluvně ukotveného „,automatického“ revidování stanovených cílů. Proto hlavním cílem tzv. druhé mezivládní konference s označením Maastricht II. bylo zhodnocení integračního posunu v otázkách HMU, SZBP a JaV, konsolidace smluvního rámce ${ }^{5}$ a pokus o řešení reformy institucí ${ }^{6}$. Tento cíl však nebyl naplněn v souladu s očeká- 
váními. Navzdory snahám o důkladnou připravenost jednání se mezivládní konference prodloužila (Turín 29. března 1996 - Amsterodam 16.-17. června 1997) a zvláště v otázce institucionální reformy nepřinesla očekávaný výsledek. Jejím definitivním výstupem byla tzv. Amsterodamská smlouva (podepsaná 2. ř́jna 1997 na úrovni ministrů zahraničních věcí), která po ratifikaci všemi členskými státy vstoupila v platnost 1. května 1999.

V institucionálních otázkách nepřinesla Amsterodamská smlouva očekávané výsledky. Členské státy EU nebyly schopné dosáhnout dohody o institucionální reformě, kterou přitom současně deklarovaly jako podmínku plánovaného rozšíření. Dokument v této věci kodifikoval pouze několik méně podstatných bodů, např. omezení počtu poslanců Evropského parlamentu na 700 tak, aby zajišt'ovali „,přiměřené zastoupení lidu států sdružených ve Společenství“ (čl. 190 Smlouvy o ES revidované Amsterodamskou smlouvou), rozšíření používání tzv. spolurozhodující procedury a přijetí zásad pro větší transparentnost rozhodování v Radě. K dalším změnám patřilo silnější postavení Evropského parlamentu v procesu volby předsedy Komise, jehož pozice byla Amsterodamskou smlouvou rovněž posílena.

Další změny ukotvené v Amsterodamské smlouvě ovlivnily institucionální strukturu pouze sekundárně, nicméně měly závažné důsledky pro další rozšíření. K opatřením tohoto typu patřilo otevření možnosti stíhat členskou zemi pro porušení ,zásady svobody, demokracie, právního státu, lidských práv a zásad společných členským státům“ (čl. 6 a 7 Smlouvy o EU revidované Amsterodamskou smlouvou). Jednalo se o zcela nový nástroj, jehož začlenění do ústavní legislativy EU bylo chápáno právě jako příprava na plánované rozšíření. Podobně v souvislosti s rozšířením bylo interpretováno zavedení „užší spolupráce“ (čl. 11 Smlouvy o ES revidované Amsterodamskou smlouvou), což je kodifikace alternativy prohloubení integrace v závislosti na vlastních možnostech a kapacitách, aniž by se tato integrace musela týkat všech členských zemí. ${ }^{7}$ Koncepce „užší spolupráce“ přirozeně obsahuje mechanismy obrany proti situacím, kdy by mohlo být rychlejšího postupu určité skupiny zemí použito k narušení stávajících společných politik a programů, proti občanství Unie a souvisejícím principům rovnosti a diskriminace nebo kdy by mohlo dojít k omezení obchodu a volné soutěže. Podmínky byly definovány pro „minimálně většinu státư“, přičemž musely být respektovány platné smlouvy, zachováno acquis communautaire a otevřenost celého systému atd. (čl. 43 Smlouvy o EU revidované Amsterodamskou smlouvou). Článek zavádějící tuto diferencovanou (nebo jinak také tzv. flexibilní) integraci rovněž garantuje dodatečné zapojení členských zemí do užší a rychlejší skupiny a zmiňuje také možnost, jak flexibilnímu postupu zabránit (Wessels 1998: 78-79). V případě, že by se členské státy cítily ohroženy novou iniciativou, mohou z „důležitých důvodů národní politiky“ použít veto a zastavit rychlejší postup partnerských států (čl. 11 Smlouvy o ES revidované Amsterodamskou smlouvou). Podobná pojistka zůstala funkční ve sféře SZBP, kde došlo k rozšíření rozhodování na základě kvalifikované většiny a k aplikaci tzv. konstruktivní abstence, která umožňuje skupině zemí o celkové váze jedné třetiny hlasů nepodílet se na hlasování a následně také na přijatém rozhodnutí, a to ani kapacitně, ani finančně. V př́ípadě nesouhlasu s daným krokem mohly země opět uplatnit klasické blokační veto (čl. 23 Smlouvy o EU revidované Amsterodamskou smlouvou).

Ve všech dalších položkách, jejichž provázanost s budoucím rozšiřováním byla zvláště důležitá, se nepodařilo dosáhnout dohody, a proto byl ke smlouvě připojen protokol s budoucími možnými návrhy řešení. Tzv. Protokol o orgánech vzhledem k rozšiřrení Evropské unie 
obsahoval dvě základní varianty řešení institucionální otázky ve vztahu k přistupování nových členů. První varianta počítala s rozšířením o maximálně pět zemí. V Komisi by potom měly být všechny země zastoupeny rovným principem; v takovém př́ipadě měl být velkým zemím odebrán post druhého komisaře. Tato koncepce předpokládala úpravu hlasovacích mechanismů v Radě. Druhou variantou byl vzrůst počtu členských zemí nad dvacet. V tomto případě měla být svolána zvláštní mezivládní konference, která měla připravit institucionální reformu, jež by vytvořila podmínky pro takto výrazné rozšíření Unie.

Pro kandidátské země, které s napětím očekávaly řešení institucionální reformy v Amsterodamské smlouvě, znamenala faktická absence reformy setrvání v nejistotě ohledně jejich budoucího zastoupení v EU. Proto v období 1997-1999 nebylo vůbec jasné, jakou pozici zaujmou budoucí členové uvnitř Evropské unie, jaký charakter bude mít celý institucionální systém a v neposlední řadě ani kolik vstoupí kandidátských zemí. Protokol uvozující možné alternativy řešení byl fakticky funkční pouze několik měsíců, protože již na zasedání Evropské rady v Kolíně nad Rýnem (3.-4. června 1999) bylo zř̌ejmé, že mezi rozšiřováním a reformou institucí je vzájemná hluboká provázanost. Po zrušení metodiky „vln rozšiřování“ (Fiala, Pitrová 2003: 227) na summitu v Helsinkách (10.-11. prosince 1999) bylo zřejmé, že členské státy musejí svolat k řešení této patové situace další mezivládní konferenci. EU již totiž nemohla počítat se vstupem ,pouhé“ pětice kandidátů, jak předpokládala první varianta protokolu, ale bylo jasné, že se institucionální struktura musí nastavit na možný vstup skupiny až 13 zemí.

Evropská unie tedy po Amsterodamské smlouvě nenabízela ČR žádný konkrétní model začlenění. Smlouva nicméně ovlivnila postavení kandidátských států již samotným odkladem institucionální reformy, protože ten znamenal také odklad rozšíření. Kromě toho se jednalo o dokument, který jednoznačně posiloval proces supranacionalizace evropských institucí. Rozšíření spolurozhodovací procedury a založení užší spolupráce bylo dokladem, že plánovaný proces rozšíření nebude pro EU impulzem k přehodnocení integrační dynamiky, ale naopak bude motivem $\mathrm{k}$ jejímu ještě intenzivnějšímu prohlubování.

Model z Amsterodamu nicméně navzdory těmto prvkům zachoval dosavadní stavební principy evropských institucí, především pak mechanismus rozložení vlivu mezi velkými a malými členy a možnost, aby v zásadních položkách včetně modelu užší spolupráce mohly státy zahájit účinnou blokádu uplatněním práva veta v Radě. Naproti tomu nově kodifikovaný model obrany základních hodnot byl vybočením z ustálených zásad integračního procesu. Až do Amsterodamské smlouvy byl totiž jedinou autoritou schopnou postihovat „,neposlušné státy“ Evropský soudní dvůr. Zavedení politické kontroly chování členských států je proto z hlediska evropských institucí ojedinělý krok. Aplikace této zásady je nicméně opatřena pojistkou „přátelského státu“, kdy pouze jediná země na straně obžalovaného stačí k tomu, aby k odsouzení „,neposlušného státu“ nedošlo. Další pojistkou je ostatně také vysoké kvorum při hlasování v Evropském parlamentu.

Hypoteticky by ČR v př́padě svého začlenění do EU již v roce 1999 získala poměrně stabilní postavení. EU nijak nezasáhla do modelu vážení hlasů, a ČR by se tedy zapojila do systému favorizujícího menší země. V souladu s historickým modelem by vstup na základě principů Amsterodamské smlouvy umožňoval, aby ČR měla stabilního komisaře a aby se její vláda rovnocenně podílela na volbě předsedy Komise a posléze na sestavování celého úřadu, přičemž 
v obou prrípadech by byla schopna návrh kandidátů na komisaře $\mathrm{v}$ okamžiku volby vetovat. V situaci, kdy by se jádro EU ubíralo směrem jdoucím proti českým národním zájmům, by ČR mohla na úrovni Rady dostatečně efektivně hájit (opět díky právu veta) svoji pozici. Lze rovněž předpokládat, že ČR by se v hypotetickém př́padě krize podařilo v rámci členských (nebo nových členských) zemí získat „partnerský stát“ a tím zabránit případnému přijetí sankcí.

\section{Institucionální model po Nice a předpokládané postavení ČR}

Další podstatnou revizi smluvních dokumentů měla přinést mezivládní konference v roce 2000, jejíž program byl určen na summitu Evropské rady v Helsinkách (10.-11. prosince 1999). Příprava evropských institucí a členských států na mezivládní konferenci byla zachycena v několika zásadních dokumentech ${ }^{8}$, v nichž se opakovaně potvrzovala neodkladnost institucionální reformy. Hlavními prioritami konference, která byla zahájena 14. února 2000, se stala velikost a složení Evropské komise, změna principu vážení hlasů v Radě, rozšíření mechanismu hlasování kvalifikovanou většinou a přijetí opatření týkajících se dalších orgánů (Pitrová 2002: 110-115). Během portugalského předsednictví byl po summitu ve Feiře (19.-20. června 2000) do programu konference začleněn další bod, kterým byla revize principu flexibility (užší spolupráce) zavedená Amsterodamskou smlouvou. Konference byla uzavřena summitem v Nice (7.-11. prosince 2000) a finální dohoda Evropské rady byla potvrzena ministry zahraničních věcí 26. února 2001.

Hlavním bodem institucionální reformy z Nice byla Komise. Smlouva v rámci protokolu o institucích uvádí, že počínaje 1. lednem 2005 odevzdají velké členské státy svého komisaře výměnou za změnu v procesu vážení hlasů. Komise byla současně omezena horní hranicí 27 členů. Bylo zároveň dohodnuto, že při dosažení této velikosti bude Radou jednomyslně přijato rozhodnutí o principu rotace komisařů mezi menšími zeměmi (čl. 4 Protokolu o rozšíření Evropské unie v prŕloze Smlouvy z Nice). Toto ustanovení definitivně odstranilo jednu z překážek pro vstup dvanácti kandidátských zemí. Za velice významnou změnu je nutno považovat změnu ve volbě předsedy Komise, který měl být podle textu novelizované Smlouvy o ES nadále volen kvalifikovanou většinou v Radě (čl. 214 Smlouvy o ES revidované Smlouvou z Nice). Současně se předpokládalo, že takto zvolený předseda bude posílen ve svých pravomocích při vedení Komise. Bude též moci přeskupovat portfolia a bude mít možnost odvolat za souhlasu ostatních členů Komise osobu, která již nadále nesplňuje požadavky, popř. nemá jeho důvěru pro plnění funkce komisaře (čl. 217 Smlouvy o ES revidované Smlouvou z Nice). Zavedení opatření, jež umožňuje předsedovi požádat člena Komise o rezignaci, je nutno interpretovat jako reakci na demisi Komise Jacquesa Santera v roce 1999.

V př́padě Rady se ve Smlouvě z Nice podařilo postoupit v otázce vážení hlasů. S platností od 1. ledna 2005 byly členským zemím přiděleny nové hlasy v rozpětí od 3 pro Maltu až do 29 hlasů pro velké členské země. Návrh na rozložení hlasů uvedený v textu prohlášení předpokládal vstup všech 12 kandidátských států s celkovým součtem všech hlasů 345 (čl. 1 Prohlášení o rozšiřrení Evropské unie v př́íloze Smlouvy z Nice). Podmínkou pro přijetí legislativního návrhu kvalifikovanou většinou na návrh Komise bude splnění daného prahu hlasů určeného v závislosti na počtu členských zemí a současně souhlas minimálně většiny členských států. V prrípadě superkvalifikované většiny, kdy Rada rozhoduje nezávisle nebo proti vůli Komise, to budou již dvě třetiny zemí. 
V textu smlouvy je dále zakomponována celá řada ustanovení dotýkajících se odstranění jednomyslného hlasování. Převážně se jedná o mechanismus voleb reprezentantů do jednotlivých orgánů. Příkladem může být nově postačující kvalifikovaná většina pro volbu předsedy Komise a následně celého orgánu, volba vysokého zmocněnce Rady a stejně tak členů Účetního dvora a poradních orgánů. Podobně je ve Smlouvě z Nice nahrazeno jednomyslné hlasování spolurozhodovacím postupem podle článku 251 revidované Smlouvy o ES v oblasti politik, kde se např. u pohybu osob, v oblasti měnové a hospodářské politiky, při hlasování o ustanoveních o kohezi, o rodinném právu apod. „kompenzuje“ ztráta vlivu jednotlivých zemí na půdě Rady tím, že je hlasování paralelně přeneseno do „druhé komory“ - Evropského parlamentu. ${ }^{9}$

Tato na první pohled pouze technická změna ovšem ve svém důsledku znamenala opět významné prohloubení integrace a ztrátu možnosti vetovat nevyhovující legislativu. Naprostou novinkou bylo ustanovení tzv. dvojí většiny, která měla zohlednit faktor počtu obyvatel. Hlasování pomocí dvojí většiny bude zahajováno na žádost kteréhokoliv členského státu. Jestliže státy formující kvalifikovanou většinu v daném hlasování neodpovídají 62 \% obyvatelstva v Unii, legislativa nebude platná (čl. 3 Protokolu o rozšíření Evropské unie v př́íloze Smlouvy z Nice).

Evropskému parlamentu byl protokolem a prohlášením přidruženým ke Smlouvě z Nice přidělen počet křesel pro všechny kandidátské země. Maximální počet poslanců byl v rozporu se zásadou přijatou v Amsterdamské smlouvě zvýšen na 732. Smlouva z Nice počítala s přerozdělením stávajících mandátů od 1 . ledna 2004 v rozpětí od 5 pro Maltu až po 72 mandátů pro velké členské země (čl. 1 Prohlášení o rozšíření Evropské unie v př́íloze Smlouvy z Nice). Německo by v tomto případě mělo 99 křesel. Tím by mělo být vyrovnáno jeho zásadní podhodnocení v Radě ministrů (čl. 2 Protokolu o rozšíření Evropské unie v př́loze Smlouvy z Nice).

Nejsnáze dosažitelné změny ve Smlouvě z Nice se týkaly úpravy počtu mandátů v poradních výborech. Růst počtu reprezentantů výboru regionů a hospodářského a sociálního výboru ohraničila Smlouva z Nice do budoucna číslem 350 (čl. 258 Smlouvy o ES revidované Smlouvou z Nice). Součet přidělených hlasů pro všech 27 plánovaných členů činí v obou případech 344 (čl. 3 Protokolu o rozšíření Evropské unie v příloze Smlouvy z Nice). Omezení ve velikosti naopak nebylo potvrzeno u Účetního dvora a Evropského soudního dvora, v nichž bude nadále jeden stát reprezentován jedním zástupcem (Protokol o statutu Soudního dvora v př́loze Smlouvy z Nice).

Z hlediska kandidátských zemí měl také význam zásah do mechanismu obrany hodnot EU (Bonde 2001: 41-44). Smlouva reviduje hlasování o porušení základních hodnot podle článku 7 Smlouvy o EU a rozšiřuje právo iniciovat hlasování na Evropský parlament. Dále umožňuje předřadit před samotné hlasování o porušení hodnot rozhodnutí o vyslání pozorovatele, který monitoruje situaci v dotčeném státě. Samotný princip se nicméně mění také v tom, že se rozhoduje o ,existenci zřejmého nebezpečí, že některý členský stát závažně poruší zásady“ (čl. 7 Smlouvy o EU revidované Smlouvou z Nice). V př́padě těchto rozhodnutí Rada rozhoduje 4/5 většinou, vysoké kvorum Evropského parlamentu zůstává v platnosti, tedy dvě třetiny odevzdaných hlasů a současně nadpoloviční většina všech poslanců. O samotném porušení hodnot se již rozhoduje standardně, tedy na základě jednomyslného hlasování v Radě a po souhlasu v Evropském parlamentu. 
V prŕípadě diferencované integrace byly Smlouvou z Nice redefinovány základní principy flexibility. Tato metoda byla navíc odděleně specifikována $v$ jednotlivých pilírích (Bonde 2001: 51-58). Smlouva potvrzuje stávající podmínky a navíc přidává, že k aktivitě na základě zesílené spolupráce může dojít již ve skupině osmi států a pouze po vyčerpání standardních možností rozvoje (čl. 43 Smlouvy o EU revidované Smlouvou z Nice). U zesílené spolupráce zůstala zachována možnost dodatečného připojení. Možnost blokování na úrovni Evropské rady byla ošetřena ,přenesením diskuse na úroveň Evropské rady“, aniž by byl způsob blokace blíže specifikován (čl. 40a Smlouvy o ES revidované Smlouvou z Nice). V rámci SZBP je užší spolupráce omezena na zahraničněpolitické postoje s výjimkou vojenských nebo obranných akcí za dozoru a garance vysokého zmocněnce pro SZBP. Alternativa blokování zde chybí (čl. 27b Smlouvy o EU revidované Smlouvou z Nice). Ve Smlouvě z Nice bylo rovněž zdůrazněno, že rozhodnutí přijatá v rámci posílené spolupráce netvoří součást acquis communautaire a mají př́imý účinek pouze ve státech, které se jí účastní (čl. 44 Smlouvy o EU revidovaný Smlouvou z Nice).

Smlouva z Nice, tedy prozatím poslední dokument revidující primární právo Unie, představuje pokus o zásadní rekonstrukci EU. Navzdory několika významným změnám se ale dokument v mnoha oblastech pouze snaží o náznak radikální reformy, kterou však fakticky odkládá do budoucnosti. Smlouva nap̌r. odebírá druhé komisaře velkým členským zemím a současně se odvolává na kapacitní limit této instituce. Důsledky stanovení limitního množství 27 členů Komise ale již nejsou ve smlouvě řešeny, protože zde není určen mechanismus rotace komisařů mezi státy ani určen počet komisařů. Smlouva tím otevřela pro některé země možnost ztráty „vlastního“ komisaře, který ovšem pro vlády znamená cenný zdroj informací, možnost podílu na tvorbě nadnárodních politik atd. Při plné realizaci rozšsiřrení by toto pravidlo nakonec pro ČR mělo možný důsledek, že ČR nebude mít přímý podíl v Komisi, která je držitelkou práva na legislativní iniciativu, správcem finančních prostředků Unie a „,bránou zájmových skupin v EU“،.

Podobně v př́ipadě Rady, kde dominovalo vážení hlasů, došlo při přijetí Smlouvy z Nice k řadě změn, které zásadně ovlivňují budoucí postavení ČR. Smlouva definovala pravidlo, které ve svém důsledku upřednostňuje před konkrétními zájmy států „zájmy obyvatel“ Unie. Ačkoliv smlouva zachovává model vážení hlasů, znevýhodňuje zároveň zájmy menších zemí, a to kvůli pravidlu tzv. dvojí většiny. Současně dochází na základě smlouvy k rozšriření položek, v nichž se hlasuje kvalifikovanou většinou. Nahrazení jednomyslného rozhodování při volbě nejvyšších představitelů EU kvalifikovanou většinou znamená, že ČR ztrácí možnost blokovat kandidáta na post předsedy Komise, čímž je dále omezena při uplatňování vlivu na složení Komise a její další strategii.

Jakmile vstoupila Smlouva z Nice v platnost, získala možnost posílené spolupráce s ohledem na budoucí rozšíření menší skupina států. Posílená spolupráce tedy není podmíněna účastí většiny. Smlouva z Nice omezila pro ČR možnost vetovat rychlejší skupinu a tím i zabránit nechtěným změnám, i když současně je zde plně garantováno pozdější připojení. Podobně lze z hlediska ČR jako nevýhodnou změnu interpretovat reformu mechanismu obrany základních hodnot. Samotné hlasování o sankcích a rozhodnutí se nezměnilo, ale redefinice porušení podmínek na „riziko budoucího porušení“ nelze považovat za výhodné pro nové členské země, a to zvláště v príípadě, kdy se jedná o tak obtížně specifikovatelné pojmy, jako jsou „demokracie“" nebo „svoboda“. 


\section{Evropský institucionální model a potenciální pozice ČR $v$ návrhu ústavní smlouvy}

Text Smlouvy z Nice předznamenal způsob řešení otázek spojených s budoucí podobou sjednocené Evropy, a tedy rovněž dalších konkrétních institucionálních otázek tím, že v doprovodném Prohlášení o budoucnosti Unie v př́loze Smlouvy z Nice byly prímo vyjmenovány nové úkoly: vymezení pravomocí mezi EU a členskými státy, vyjasnění postavení Charty základních práv EU, zjednodušení smluv, řešení úlohy vnitrostátních parlamentů v ,,architektuře Evropy“ apod. Další postup byl určen v tzv. laekenské deklaraci přijaté na stejnojmenném summitu Evropské rady (14.-15. prosince 2001), kde byl již jako hlavní nástroj diskuse definován tzv. Konvent o budoucnosti EU ${ }^{10}$ (Deklarace o budoucnosti EU 2001: 7). Konvent poprvé zasedl 28. února 2002 a své působení ukončil 10. července 2003. Jeho předseda předložil 18. července text „Návrhu smlouvy zakládající ústavu pro Evropu“ (dále jen ústava). Mezivládní konference navazující na Konvent byla zahájena 4. října 2003 v Římě a na svém závěrečném zasedání opět v Ř́mě (12.-13. prosince 2003) návrh nové smlouvy nepodpořila; další vývoj reformy prostřednictvím evropského ústavního dokumentu proto zůstal otevřen (Norman 2003).

Předložená ústava je dokumentem s 465 články, ${ }^{11}$ v nichž jsou vymezeny hodnoty, cíle, kompetence EU, ale také zásady provádění politik a některá zcela nová institucionální pravidla. Vrcholem institucionálního schématu a logicky také první zásadní změnou je reforma předsednictví EU. Ústava ř́ká, že setkání hlav států a vlád se má standardně odehrávat jednou za tři měsíce pod vedením předsedy Evropské rady, což je jedna z ústavou předpokládaných nových funkcí. Předseda Evropské rady, který nemůže podle návrhu ústavy současně vykonávat vnitrostátní mandát, by měl být volen kvalifikovanou většinou na dobu 2,5 roku s možností jednoho znovuzvolení (čl. I-21 ústavy). Změny týkající se předsednictví EU se nicméně již zásadně nedotkly povinností předsedajícího zasedání Evropské rady. Výjimkou je posílení mandátu k reprezentaci EU navenek v oblasti SZBP (čl. I-21 ústavy).

Pokus o centralizaci a federalizaci institucionálního modelu navrhovaného ústavou byl patrný také při rekonstrukci Evropské komise, která byla jako celek významně posílena, a to díky specifikaci řady jejích úkolů. Smlouva přímo zmiňuje, že Komise podporuje obecný „evropský zájem“, dbá na uplatňování ústavy, dohlíží na realizaci právního řádu, spravuje rozpočet, řídí programy apod. Za tímto účelem vykonává úkoly koordinační, řídící a prováděcí. Až na výjimky potvrzuje ústava nepsaný monopol Komise v oblasti legislativní iniciativy ${ }^{12}$ (čl. I-25 ústavy). Návrhem ústavy by byly také posíleny vazby mezi Komisí a dalšími orgány, které má Komise povinnost pravidelně informovat (čl. I-13, III-95, III-321 ústavy).

Pravděpodobně největší pozornost byla věnována návrhu, aby od 1. listopadu 2009 existovaly dvě kategorie komisařu: „evropští komisaři“ s hlasovacím právem a „komisaři“ bez práva hlasovat. Kolegium Komise mělo být do budoucna složeno z předsedy, místopředsedy a 13 evropských komisařù ${ }^{13}$ (čl. I-25 ústavy). Rotaci evropských komisařu ústava nespecifikovala s výjimkou podmínky, aby tato rotace odpovídala zásadě rovnosti, odrážela demografickou a zeměpisnou různorodost členských států EU a aby bylo zajištěno, že celkový rozdíl mezi funkčním obdobím dvou států nebyl větší než jedna (čl. I-25 ústavy). Komise měla být volena dvoustupňově, tedy v prvním kole předseda a až posléze Komise jako celek. Změnou bylo, že kandidát na předsedu Komise měl být nominován s přihlédnutím k výsledkům voleb 
do Evropského parlamentu. Novinku rovněž znamenala časová lhůta jednoho měsíce pro př́ípad, že se Evropská rada na nominaci nového kandidáta nedohodne (čl. I-26 ústavy). Volba členů Komise v druhém kole předpokládala povinnost zemí, které podle mechanismu rotace nabízejí komisaře, sestavit listiny tř́i kandidátů reprezentujících obě pohlaví. Kritériem nominace nemá být „pouze“ jejich nezávislost, ale nově také jejich kvalifikace a „evropanstvi“"14 (čl. I-26 ústavy). Předseda vybere z každého seznamu jednu osobu a tím nominuje 13 evropských komisařu. K takto navrženému kolegiu je poté dosazen místopředseda, který je rovněž ministrem pro zahraniční záležitosti, a nevolení komisaři bez hlasovacího práva. Takto sestavená skupina předstupuje před Evropský parlament. Během funkčního období má potom předseda možnost odvolat nejen komisaře, ale i evropského komisaře, a to kdykoliv a nezávisle na stanovisku celé Komise (čl. I-26 ústavy).

Změny týkající se podoby Rady ministrů byly zaměřeny na zpřehlednění systému a revizi hlasování. Rada má podle ústavy dvě základní formace. ${ }^{15}$ Jednou je tzv. všeobecná a legislativní rada a druhou rada ministrů pro zahraniční záležitosti.

Všeobecná a legislativní rada zajišt’uje konzistenci celého působení Rady ministrů, je postavena na principu rotace předsednictví, které je prodlouženo na období nejméně jednoho roku. Tato rada se dále ještě rozděluje na všeobecnou a legislativní (normotvornou, právní) radu. Úkolem rady pro všeobecné záležitosti je za asistence Komise připravovat zasedání Evropské rady. Normotvorná rada má za úkol přijímat ve spolupráci s Evropským parlamentem legislativu. Formát Rady je při plnění legislativních úkolů tvořen jedním či dvěma ministry odpovědnými v členských zemích za daný sektor (čl. I-23 ústavy).

Druhou formací je rada ministrů pro zahraniční záležitosti, které trvale předsedá ministr pro zahraniční záležitosti EU (čl. I-23 ústavy). Postavení ministra zahraničí EU navazuje na funkci vysokého zmocněnce pro SZBP. Ministr pro zahraniční záležitosti je volen kvalifikovanou většinou v Evropské radě po souhlasu předsedy Evropské komise a stejně může být také odvoláván (čl. I-27 ústavy). Ministr pro zahraniční záležitosti EU je současně jedním z místopředsedů Komise s pověřením koordinovat vnější vztahy. Tato pozice, která je označována jako tzv. „dvojí klobouk“, má za úkol zajistit větší koordinaci a soulad v otázce vnějších vztahů EU. Pravomoci ministra pro zahraniční záležitosti EU se tedy zásadně neodlišují od dosavadních pravomocí vysokého zmocněnce pro SZBP (čl. III-197, 203-205 ústavy).

Podstatná změna byla $\mathrm{v}$ ústavě navržena $\mathrm{v}$ oblasti rozhodovacích pravidel. Pro Evropskou radu zůstalo převážně zachováno rozhodování na základě jednomyslnosti (čl. I-20 ústavy), nicméně ústava definovala za určitých okolností hlasování kvalifikovanou většinou současně pro Radu i pro Evropskou radu. Jedná se o přesně vymezené př́ípady a volbu čelních představitelů Unie (čl. I-24 ústavy). Evropská rada také měla podle návrhu mít zvláštní možnost odblokovat pomocí jednomyslného hlasování nutnost hlasovat jednomyslně v konkrétních oblastech v Radě ministrů. Užití této možnosti ale musela Evropská rada oznámit čtyři měsíce předem národním parlamentům členských zemí (čl. I-24 ústavy). Pro Radu ministrů s výjimkou formátu zahraničních záležitostí ${ }^{16}$ zůstalo jako standard zachováno hlasování kvalifikovanou většinou (čl. I-22 ústavy), která měla být od 1. listopadu $2009^{17}$ definována jako většina členských států a nejméně tři pětiny obyvatelstva EU (čl. I-24 ústavy). Tím ústava nahradila podmínku počtu států a hlasů podmínkou počtu států a minima populace $(60 \%)$. Podobně byla upravena také superkvalifikovaná většina. 
V př́padě Evropského parlamentu se pro období po roce 2009 mají určit počty mandátů jednotlivých zemí s dodržením nově definovaného stropu 736 křesel a na základě zásady, že minimální zastoupení jedné země budou čtyři mandáty (čl. I-19 ústavy). Posílena byla povinnost ostatních orgánů informovat pravidelně parlament (srov. I-13, III-321, I-21, III-205 ústavy). Zásadních změn parlament doznal v oblasti legislativní a rozpočtové. Ve sfére legislativní byla do ústavy ukotvena pouze jediná procedura, a to odpovídající plnému uplatnění parlamentního veta (čl. III-302 ústavy). Rozpočtové pravomoci parlamentu byly jednoznačně posíleny tím, že se odstranilo členění rozpočtových výdajů na povinné a nepovinné (čl. III-310 ústavy).

Ústava se nedotkla mechanismu obrany základních hodnot EU, pouze redefinovala původní „základní hodnoty“. Nad rámec dosavadního výčtu zmiňuje ústava úctu k lidské důstojnosti (čl. I-2 ústavy). V případě posílené spolupráce, což je opět v souvislosti s rozšířením EU významná položka, byly zachovány dřive dané principy s některými výjimkami: velikost minimální skupiny byla stanovena na jednu třetinu států a souhlas se založením posílené spolupráce musí udělit nejenom Rada, ale také Evropský parlament (čl. III-325 ústavy). $\mathrm{O}$ připojení další země podle ústavy rozhoduje Komise, která se vyslovuje k připravenosti kandidáta na posílenou spolupráci tzv. „zjištěním“ (čl. III-326 ústavy). V návrhu se navíc objevil zcela nově termín ,úzká“, popř. „strukturovaná“ spolupráce v oblasti obrany (čl. I-40 ústavy). Pravidla pro tento zpo̊sob „,posílené spolupráce“ udávají, že jestliže si stát přeje připojit k této formě spolupráce v oblasti obrany, rozhodují o tom pouze členové Rady, kteří skupinu strukturované spolupráce vytvářejí. Spolupráce byla nicméně koncipována jako otevřená vůči všem členským státům (čl. III-214 ústavy).

Návrh se také poměrně významně dotkl vztahu mezi institucemi EU a vnitrostátními parlamenty, které nejenže mohou dále komentovat legislativní návrhy, ${ }^{18}$ ale nově získaly také právo vyslovit se v otázce prŕípadného porušení principu subsidiarity a proporcionality, jež jsou základními stavebními principy EU (srov. čl. I-9 ústavy). Parlamenty do budoucna již nevedou pouze konzultace, ale mohou předat Komisi odůvodněné stanovisko, které se týká souladu návrhu právního předpisu s výše zmíněnými principy. Komise nemusí stanovisku vyhovět, ale musí svůj postoj odůvodnit (srov. Protokol o používání zásad subsidiarity a proporcionality v př́loze ústavy). Svá zjištění mohou parlamenty zaslat také předsedům Evropského parlamentu a Komise ve lhůtě 6 týdnů od získání předlohy. Pokud odůvodněné stanovisko o nedodržení principu subsidiarity vyjádří nejméně jedna třetina všech hlasů přidělených vnitrostátním parlamentům (každá komora v prŕípadě bikamerálního systému má jeden hlas, v př́pade jednokomorového dva hlasy), má Komise povinnost svůj návrh přezkoumat. V oblasti prostoru svobody, bezpečnosti a práva stačí pouze jedna čtvrtina hlasů. Krajní možností je podání žaloby na neplatnost podle čl. III-266 ústavy. ${ }^{19}$

Z hlediska celé institucionální soustavy znamenalo výraznou změnu ukotvení alternativy vystoupení z EU, které se doposud nevyskytovalo v žádné z novelizací primárního práva ani ve smlouvách zakládajících. Ústava zmiňuje možnost dobrovolného vystoupení. Žádost je předkládána Evropské radě, která dále postupuje řešení věci Radě ministrů, jež má za úkol vypracovat s vystupujícím státem dohodu o vystoupení. Dohoda je v Radě přijímána kvalifikovanou většinou po souhlasu Evropského parlamentu. Vystupující stát se žádného hlasování neúčastní. Pro př́pad, že by se dohodu upravit nepodařilo, přestává ústava pro vystupující stát platit za dva roky od data oznámení úmyslu vystoupit, pokud není dohodnuto jinak (čl. I-59 ústavy). 
Návrh nového smluvního textu představoval řadu změn, které ve své podstatě znevýhodňovaly postavení menších a malých členů EU. Současně však tento návrh postoupil vpřed v mnoha položkách, jež byly dlouhou dobu nepřijatelné a o jejichž zakomponování do smluvního systému se původně vůbec neuvažovalo. Příkladem této kategorie zásahů může být zakotvení mechanismu vystoupení z EU nebo odstranění rozdělení rozpočtu na přímé a neprrímé výdaje. Bližší studium konkrétních institucionálních změn nicméně naznačuje, že postavení menších a málo lidnatých zemí - mezi nimiž bude i ČR - by bylo oslabeno a po přijetí ústavy by se zmenšila možnost obhajoby českých národních zájmů.

Pomineme-li volbu předsedy EU, jehož funkce je již sama o sobě vyjádřením nerovnosti členů EU, protože vzhledem k SZBP lze přepokládat zvolení reprezentanta z menší členské země pouze výjimečně, je nutno vidět negativní dopad ústavního návrhu především v reformě Komise a Rady. Ústavou definovaná Komise vytváŕí prvek rivality mezi velkými a malými zeměmi, resp. mezi zeměmi zastoupenými v kolegiu a zbytkem států. Ačkoliv sama Komise nevidí pro toto řešení opodstatnění (Prodi 2003), ocitly se země s komisaři bez hlasovacího práva $\mathrm{v}$ jednoznačně nevýhodném postavení, které není ve smlouvě nijak kompenzováno. Smlouva neříká, zda mohou být „druhořadí komisaři“ držiteli nějakého úřadu, nebo dokonce př́tomni na všech jednáních Komise. Komisaři mají ale stejnou odpovědnost za činnost úřadu před Evropským parlamentem, i když se chodu Komise a jejich rozhodnutí fakticky neúčastní. Komise rozdělená na „komisaře s vlivem, právy a informacemi““ a komisaře bez těchto práv je dále postižena významnou politizací. Dá se očekávat, že předseda Komise, volený s ohledem na výsledky evropských voleb, bude při výběru upřednostňovat spolupracovníky s obdobným politickým zaměřením. Lze také přepokládat, že Evropský parlament na základě poměrů sil mezi frakcemi jeho volbu podpoří.

Dalším reálným předpokladem je prohlubující se supranacionalizace personálního obsazení Komise, jejíž členové musí být zárukou „evropanství“. Uplatněním těchto principů by se Komise významně vzdálila koncepci nezávislého „mozkového trustu“ reprezentujícího způsoby řešení v rámci celé EU. ČR jako menší členská země by ke své omezené možnosti získat resort první kategorie mohla být ještě dočasně odsunuta do pozice bez evropského komisaře, což by její postavení, stejně jako postavení dalších zemí ve stejné situaci, ztížilo. Česká vláda by tak měla významně omezený manévrovací prostor pro nominaci komisaře, který by musel odpovídat kritériu „evropanství“, politické př́slušnosti a povinně též „genderového aspektu výběru“. Po dosazení komisaře by ČR nejen ztratila přímé napojení na dění v Komisi, a tím přerušila informační tok, ale také by neměla jistotu jeho stabilního působení, protože ústava dává předsedovi Komise možnost odvolat členy Komise kdykoliv a nezávisle na stanovisku celého úr̆adu. ${ }^{20}$

Pro zemi velikosti ČR by mělo zcela zásadní význam odstoupení od procedury vážení hlasů, která je výsledkem uplatnění principu politické solidarity a umožňuje malým partnerům zvýšit vliv na úroveň, jež umožňuje komunikaci s velkými zeměmi EU. Nahrazení procedury vážených hlasů principem rozhodování podle populační síly zemí znamená podstatné zmenšení vlivu menších a malých zemí. Zájmy malých zemí zůstávají do budoucna bráněny pouze podmínkou, že je zapotřebí dosáhnout souhlasu většiny zemí, a předpokladem koaliční metody jednání. Transformace kvalifikované většiny směrem k většině formované na základě velikosti populace jednoznačně posiluje skupinu velkých zemí. 
Ústavní smlouva jako celek představuje významný krok směrem k supranacionalitě. Patrné je to např. v odstranění koncepce pilířů, ve vytvoření právní subjektivity EU, v možnosti nastolit hlasování kvalifikovanou většinou v Radě, aniž by byla svolána mezivládní konference k revizi smluv nebo v možnosti vytvoření strukturované spolupráce $\mathrm{s}$ nejistou možností připojení. Tato tendence k posilování supranacionálních prvků v průběhu procesu přistupování znamená ve svých důsledcích také oslabování vlivu nových zemí v rámci Evropské unie a snižuje možnost ČR hájit uvnitř Unie své zájmy.

\section{Závěr: Proměny postavení ČR v jednotlivých smluvních koncepcích}

Na základě kvalitativní analýzy jsme se snažili ukázat, jak se v návaznosti na revize smluv měnily podmínky pro působení ČR v institucionální struktuře EU po př́padném vstupu. Postupné oslabování předpokládané pozice ČR v rámci EU by bylo samozřejmě vhodné vyjádřit také kvantitativně. Proto by bylo ovšem nezbytné srovnání konkrétních modelů začlenění České republiky, jak se objevovaly v průběhu procesu přistupování. Takovéto srovnání není však možné, protože nelze rozumně komparovat odlišné fáze permanentně se vyvíjejícího útvaru a ani nelze důsledně kvantitativně vyjádřit různé modely rozšíření. V období let 1993-2004 nebyla stabilní žádná z nezbytných proměnných, které by umožnily kvantifikovat postavení ČR v orgánech EU. V průběhu této doby se totiž měnil celkový počet členských států EU, nebyly stanoveny limitní počty hlasů a křesel v jednotlivých orgánech a chybělo také určení počtu kandidátských zemí, jež budou přijaty. Jak ukázala Smlouva z Nice a návrh ústavy, měnily se také principy hlasování a vztah k vážení hlasů v institucích EU. Oba faktory mají přitom př́mý vliv na zhodnocení postavení konkrétních zemí v EU.

V situaci, kdy vstupní proměnné nedovolují zhodnocení a komparaci reálných alternativ, je možné se pokusit vyjádřit proměny předpokládaného postavení ČR pomocí experimentálního modelu. Podmínkou jeho vytvoření bylo stanovení jedné dané (stabilní) proměnné. V tomto modelu je konstantní hodnotou počet členských států. Model je založen na předpokladu, že Česká republika vstupuje do EU tvořené stávajícími patnácti členskými zeměmi. Veškeré další zásady a pravidla, které vznikly během procesu přistupování součástí jednotlivých smluvních novelizací, jsou aplikovány na model 15 členských států + Česká republika. ${ }^{21}$

Model 15+1 se soustředí výhradně na posouzení výše procentuálního vlivu v klíčových orgánech legislativního procesu. Cílem experimentu je srovnat nárůst či pokles nabídky členských států EU vůči ČR (15+1) v otázce zastoupení v Komisi, Evropském parlamentu a v Radě EU. Následující tabulka (tab. 1) zachycuje alternativy pro přistoupení ČR v době, kdy platila pravidla Amsterodamské smlouvy, pravidla stanovená textem Smlouvy z Nice, podmínky definované Př́istupovou smlouvou, v níž byl na základě protestu ČR upraven počet přidělených křesel v Evropském parlamentu, a konečně model navrhovaný ústavou.

Také experimentální model vyjádřený v Tabulce 1 dokládá, že jednotlivé smluvní novely znamenaly pro ČR zásadní proměnu její potenciální pozice v EU. Pokles vlivu ČR v rámci jednotlivých modelů probíhal strměji v Radě než v Evropském parlamentu. Na půdě parlamentu byl pokles vlivu po přijetí Smlouvy z Nice pouze nepatrný $(0,2 \%)$ a po úpravě počtu poslanců z původních $20 \mathrm{v}$ textu Smlouvy z Nice na 24 v Přístupové smlouvě byl dokonce znovu o 0,2 \% zvýšen. Naproti tomu v Radě, která je mnohem významnější pro rozhodovací procesy, zazna- 


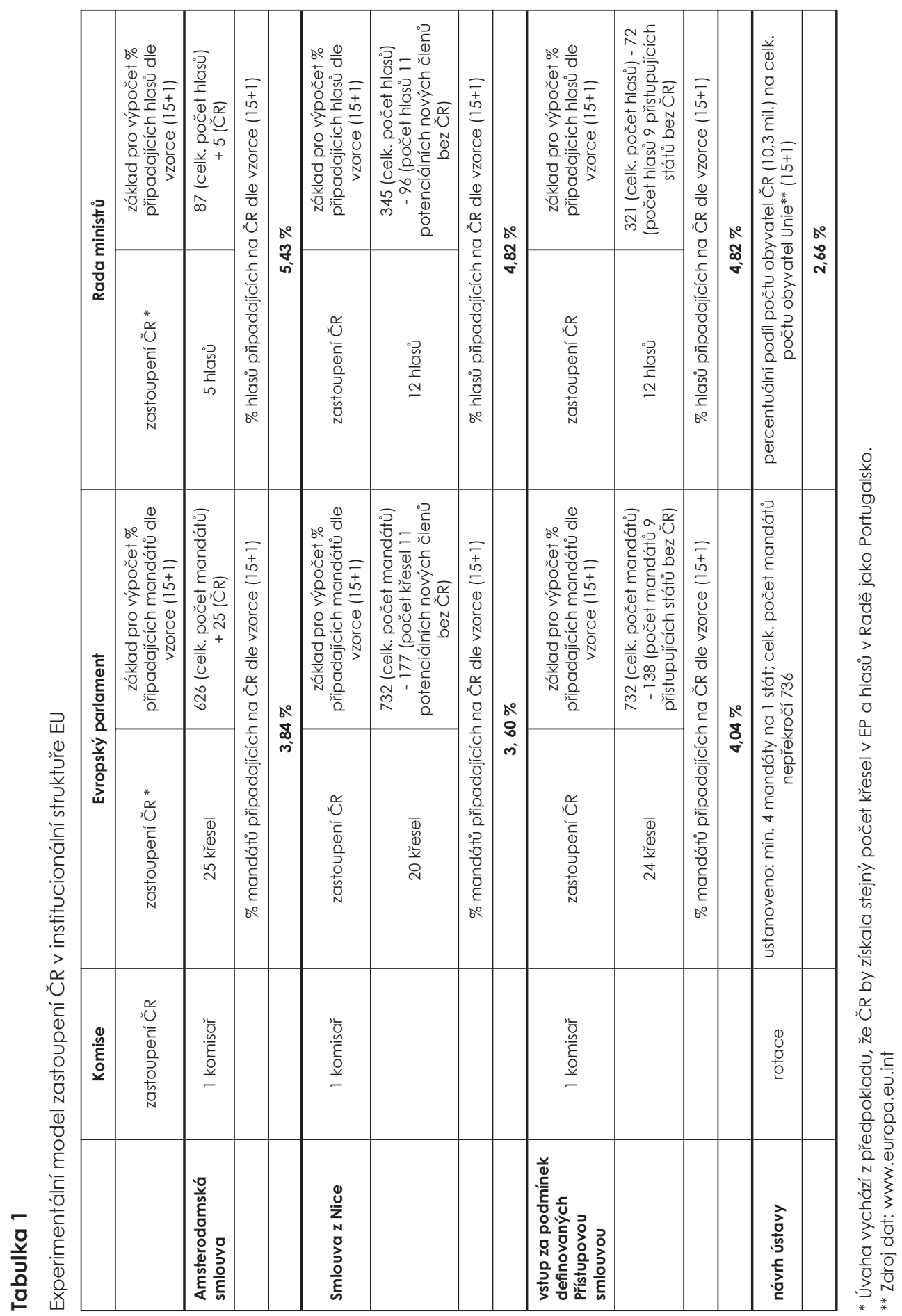


menala podle představy z Nice Česká republika pokles o 0,6 \%. Postavení ČR v Radě by potom bylo poloviční ve srovnání s modelem $\mathrm{z}$ Amsterodamu v případě, že by došlo ke schválení ústavy. Při srovnání „ústavní nabídky“ pro Českou republiku se situací v momentu vstupu, a tedy i s modelem, o němž bylo rozhodováno v referendu v roce 2004, je zřejmé, že ústavní návrh s 2,66\% podílem v Radě pokrývá pouze 55 \% původní pozice očekávané při vstupu. Vliv České republiky ohrožuje nejenom ústavní model Rady, ale též budoucí rotace v Komisi. V př́ípadě parlamentu by změna v zastoupení České republiky ani zde nebyla významná. Konkrétní ústavní návrh sice pro parlament chybí, ale nelze předpokládat podstatnější změnu vzhledem k zafixování celkového počtu hlasů na hodnotě 736 místo původních 732 .

\section{Tabulka 2}

Model zastoupení ČR v institucionální struktuře EU po vstupu do EU

\begin{tabular}{|c|c|c|c|c|c|}
\hline \multicolumn{6}{|c|}{ srovnání: } \\
\hline & Komise & \multicolumn{2}{|c|}{ Evropský parlament } & \multicolumn{2}{|c|}{ Rada ministrů } \\
\hline & zastoupení ČR & zastoupení ČR & $\begin{array}{l}\text { základ pro } \\
\text { výpočet \% } \\
\text { mandátů } \\
\text { priipadajících } \\
\text { na ČR }\end{array}$ & zastoupení ČR & $\begin{array}{c}\text { základ pro } \\
\text { výpočet \% hlasů } \\
\text { připadajících } \\
\text { na ČR }\end{array}$ \\
\hline \multirow[t]{3}{*}{$\begin{array}{l}\text { realita vstupu } \\
\text { dle Přístupové } \\
\text { smlouvy (vzorec } \\
15 \text { stávajících } \\
\text { členů }+10 \\
\text { nových členů } \\
\text { včetně ČR) }\end{array}$} & 1 komisař & 24 křesel & $\begin{array}{l}732 \text { (celk. } \\
\text { počet mandáto } \\
\text { včetně } 10 \\
\text { nových členů) }\end{array}$ & 12 hlasů & $\begin{array}{l}321 \text { (celk. počet } \\
\text { hlasů včetně } 10 \\
\text { nových členů) }\end{array}$ \\
\hline & & \multicolumn{2}{|c|}{$\begin{array}{c}\text { \% mandátů pr̆ipadajících na ČR } \\
\text { dle vzorce }(15+10)\end{array}$} & \multicolumn{2}{|c|}{$\begin{array}{l}\text { \% hlasů príipadajících na ČR dle } \\
\text { vzorce }(15+10)\end{array}$} \\
\hline & & \multicolumn{2}{|c|}{$3,28 \%$} & \multicolumn{2}{|c|}{$3,74 \%$} \\
\hline
\end{tabular}

Srovnání jednotlivých eventualit s reálných stavem $(15+10)$ v Tabulce 2 dokládá, že při zachování principu vážení hlasů v Radě, který vychází k historického posílení slabších partnerů a úměrného snížení vlivu velkých států, získala Česká republika 3,74\% vliv v Radě a 3,28\% podíl na zastoupení v Evropském parlamentu, a to navzdory skutečnosti, že zastupuje pouze 2,3 \% obyvatel rozšiŕené EU. Srovnání hypotetického modelu s reálnými podmínkami vstupu také ukazuje, že případné přijetí návrhu evropské ústavy ve stávající podobě by znamenalo oslabení pozice ČR uvnitř EU. Ve smluvních revizích se v posledním desetiletí zřetelně projevují tendence k supranacionalizaci Unie a souběžné pokusy o zavedení „populačního“ kritéria, jež oslabuje politicky nezbytné zvýhodnění menších zemí. Všechny tyto faktory přispívají k tomu, že se míra předpokládaného vlivu ČR v EU pozvolna snižuje. Pokud by proces sjednocování pokračoval v rámci uvedených tendencí i poté, co se ČR stane členem Evropské unie, lze očekávat, že se její postavení uvnitř institucionální struktury bude ve srovnání se současným stavem nadále oslabovat. 


\section{Poznámky}

1 Ratifikační proces byl obtížný v Norsku (neschváleno) a v Dánsku (schváleno na druhý pokus), ale také ve Francii (velice těsný výsledek referenda), Velké Británii (hlasování o smlouvě spojeno s otázkou důvěry vládě) a v Německu (smlouva zkoumána Ústavním soudem). V závěru procesu získaly ze smlouvy výjimky (opt-outs) Velká Británie a Dánsko (Fiala, Pitrová 2003: 132-136).

2 Např́klad ve 27 členné Unii by mohlo být rozhodnutí přijato 50 \% obyvatel Unie a zablokováno již pouhými 10 \% (Přizpůsobení institucí ve prospěch úspěšného rozšíření 1999).

3 Blokační menšina se pohybovala okolo $30 \%$, ale od přijetí tzv. Ioaninského kompromisu z roku 1994 jí bylo možno dosáhnout již v rozmezí 25-30 \% hlasů. V takovém př́ípadě Unie odstupuje od rozhodnutí, které podle ní není podpořeno dostatečnou politickou vůlí (srov. Fiala, Pitrová 2003: 212-213).

4 Jedná se o Německo, Velkou Británii, Francii, Itálii a Španělsko.

5 Šlo zde o přečíslování původních smluvních kompilátů, čímž mělo být dosaženo novelizace.

6 Úkoly v oblasti institucí jsou zachyceny ve Zprávě o fungování Smlouvy o EU prezentované Evropskou komisí 10. května 1995 (Zpráva o fungování Smlouvy o EU 1995) a v práci tzv. reflexní skupiny složené z představitelů členských států, Evropského parlamentu a Komise (Postupová zpráva předsedy reflexní skupiny pro mezivládní konferenci 1996). Oba dokumenty hovořily o „zjednodušení a vyjasnění činnosti institucí“.

7 Je nutné zdůraznit, že ve skutečnosti se nejedná o vícerychlostní model, protože ten by předpokládal, že se v určitém časovém odstupu připojí všichni členové. Tato podmínka ale ve smlouvě není. Je proto vhodnější řadit tento koncept pod pojem variabilní geometrie, v němž si státy nad rámec základního modulu volí další integrační oblasti. V „eurožargonu“ se nicméně často užívá příměru vícerychlostní, příp. dvourychlostní Evropa.

$8 \quad$ Prvním z nich byla nezávislá analýza s názvem Institucionální důsledky rozšíření publikovaná 18. ř́jna 1999 a známá také jako „zpráva tří moudrých“ (R. von Weizsäcker, D. Simon a J. L. Dehaen). Druhým zásadním dokumentem z 10. listopadu 1999 bylo Přizpůsobení institucí ve prospěch úspěšného rozšíření.

9 K širšímu užití kvalifikované většiny při rozhodování v Radě dochází také ve 2. pilírí SZBP (srov. hlava V Smlouvy o EU revidované Smlouvou z Nice).

10 Konvent byl složen z 15 reprezentantů hlav států a vlád členských zemí, 30 zástupců národních parlamentů, 16 reprezentantů Evropského parlamentu a 2 zástupců Komise. Kandidátské země byly zastoupeny stejným způsobem, ale bez možnosti „blokovat jakýkoliv konsensus, k němuž by členské státy dospěly“. Blíže k mandátu Konventu a textu laekenské deklarace viz Pitrová (2003).

11 Jedná se o velice obsáhlý dokument, který začleňuje dosavadní smlouvy a pokouší se o charakteristiku základních principů. Je složen z části I. - pokus o základní charakteristiku a představení práv, povinností, hodnot EU a pojmů, II. - text Charty základních práv Unie, III. - detailní popis politiky a institucionálních vazeb, IV. - závěrečná a přechodná ustanovení. Tento text sleduje pouze nejvýznamnější změny, a to výhradně v oblasti institucí. K problematice ústavy blíže např. Pitrová (2003).

12 Ústava formalizovala standardní, ale dosud nezmiňovanou tzv. sekundární legislativní iniciativu, při níž Komise reagovala na výzvy Rady či parlamentu (srov. čl. III-234, III-248 ústavy).

13 Ústava nezmiňuje celkový počet komisařů. Pouze uvádí, že předseda volí komisaře bez volebního práva podle stejného kritéria jako členy kolegia a že tito komisaři pocházejí ze všech ostatních členských států. Je tedy zajištěno, že země s evropskými komisaři nezískají ještě statut komisaře bez hlasovacího práva. Není ale již zřejmé, zda všechny země budou mít komisaře (srov. čl. I-25 ústavy). 
V anglickém originále „European commitment“. Tato změna je z hlediska historie Evropské komise ojedinělá.

15 Ústava přistoupila $\mathrm{k}$ odstranění pomyslných piliřro maastrichtského chrámu, proto byl název Rada EU nahrazen původním termínem Rada ministrů. Ve skutečnosti se kromě rozdělení na dvě základní formace vyskytuje v ústavě ještě Rada pro eurozónu (srov. např. čl. III-88 ústavy).

16 V Radě ministrů pro zahraniční záležitosti se rozhoduje kvalifikovanou většinou jen v př́padě, že takto Rada jedná na základě rozhodnutí Evropské rady o strategických zájmech, projednávají se akce či postoje na návrh Evropské rady nebo na návrh se speciální žádostí Evropské rady, dále při implementaci akce, postoje, či při volbě zvláštních reprezentantů apod. Ve všech př́ípadech je ale zachována možnost zablokovat hlasování přsunutím na úroveň Evropské rady (čl. III-201 ústavy). Zachována je rovněž možnost konstruktivní abstence (čl. III-201 ústavy).

17 Do tohoto data upravuje rozložení vlivu zvláštní protokol, který vychází z textu Smlouvy z Nice. Do této doby je také platná tzv. dvojí většina z Nice.

18 Ústava rozvíjí nástroje z Amsterodamu a zpřesňuje, že rozhodnutí o aktu v Radě nesmí být přijato na pořad jednání Rady dříve než 10 dní od jeho zápisu (Protokol o úloze vnitrostátních parlamentů v Evropské unii v př́loze ústavy). Ústava také rozvádí nutnost poskytovat vnitrostátním parlamentům roční program návrhů právních předpisů, větší pozornost věnuje meziparlamentní spolupráci $\mathrm{v}$ rámci COSAC atd.

19 Žalobu podávají státy, a nikoliv přímo vnitrostátní parlamenty.

20 Takto definovaná Komise může způsobit také celou řadu dalších problémů, jako např. ztrátu „kolektivní paměti“ Komise, vzájemné tlaky mezi zastoupenými a „méně zastoupenými“ zeměmi, nepřijatelnost jejich návrhů v Radě, narušení kolegiality Komise a preferenci duálních vazeb komisař-předseda Komise atd.

21 Model 15+1 přirozeně nereflektuje skutečnost, že mnohé ze zásahů do institucionálního schématu byly navrženy jako „obrana velkých členských státư“ pro stav, který nastane až po rozšíření. Př́íkladem může být hlasování dvojí většinou z Nice, hlasování na principu „většiny obyvatel“ předpokládané v ústavním návrhu nebo např. aspekt koaličního vyjednávání, který ovlivňuje stanovení přesné hladiny pro kvalifikovanou většinu. Některé z kvalitativních rizik a výzev smluvních novelizací ale byly již v tomto textu vyjádřeny.

\section{Bibliografie}

Amsterodamská smlouva. 1999. Praha: Ústav mezinárodních vztahů.

Bonde, J.-P. 2001. The treaty of Nice - explained. Vindrose.

Deklarace o budoucnosti EU přijatá na zasedání Evropské rady konané ve dnech 14.-15. prosince 2001. 2002. Dokumenty Evropské unie. Př́loha Mezinárodní politiky 2/2002.

Fiala, P., Pitrová, M. 2003. „Dokončování příprav na východní rozšíření EU“. In P. Fiala, M. Pitrová. (eds.) Rozšiřování ES/EU. Brno: Masarykova univerzita, s. 225-236.

Fiala, P., Pitrová, M. 2003. Evropská unie. Brno: CDK.

Institucionální dopady rozšíření. 1999. [HTML dokument] dostupný z: http://www.europa.eu.int/ igc2000/repoct99_en.htm

Mazey, S., Richardson, J. 1994. „The Commission and the lobby“. In G. Edwards, D. Spence (ed.) The European Commission. London: Cartemill, s. 169-201.

Norman, P. 2003. The accidental constitution. Brussels: Eurocommet.

Pitrová, M. 2003. „Evropská ústava: institucionální návrhy a jejich důsledky“. Politologický časopis 4: 315-337. 
Pitrová, M. 2002. Institucionální struktura Evropské unie. Vliv integračních paradigmat na výstavbu institucí. Brno: Nauma.

Postupová zpráva předsedy reflexní skupiny pro mezivládní konferenci. 1996. Dokumenty Evropské unie. Př́loha Mezinárodní politiky 10, 11, 12/1995.

Prodi, R. 2003. [HTML dokument] dostupný z: http://www.europa.eu.int/rapid/start/cgi/ guesten.ksh?p_action.getfile $=$ gf $\& d o c=S P E E C H / 03 / 607|0|$ RAPID\&lg=EN\&type $=$ PDF

Přizpůsobení institucí ve prospěch úspěšného rozšíření. 1999. [HTML dokument] dostupný z: http://europa.eu.int/comm/archives/igc2000/offdoc/index_en.htm\#contributions

Sherrington, P. 2000. The Council of Ministers. London: Pinter.

Smlouva o Evropské unii. Smlouva o založení Evropského společenství 1994. Praha: Victoria Publishing.

Treaty of Nice. Official Journal of the European Communities, 2001. C 80, Volume 44, 10 March 2001. [HTML dokument] dostupný z: http://europa.eu.int/eur-lex/en/treaties/dat/ nice_treaty_en.pdf

Ústava EU. Návrh smlouvy zakládající ústavu pro Evropu. Draft Treaty establishing the Constitution for Europe. [HTML dokument] dostupný z: http://europa.eu.int/futurum/ constitution/index_en.htm

Wessels, W. 1998. „Flexibility, differentiation and closer cooperation“. In M. Westlake (ed.) The European Union beyond Amsterdam. London: Routledge, s. 76-98.

Zpráva Evropské komisi o fungování Smlouvy o Evropské unii. 1995. Dokumenty Evropské unie. Př́loha Mezinárodní politiky 7/1995.

\section{Autoři}

Prof. PhDr. Petr Fiala, Ph. D. (1964), děkan FSS MU, působí jako profesor politologie a držitel Jean Monnet Chair na Katedře mezinárodních vztahů a evropských studií FSS MU a je ředitelem Mezinárodního politologického ústavu Masarykovy univerzity v Brně. Specializuje se na komparativní politologii, evropskou politiku a na výzkum politické dimenze náboženství. Autor, spoluautor a editor mnoha knižních monografií, studií, článků a publicistických textů. Kontakt: pfiala@fss.muni.cz

PhDr. Markéta Pitrová, Ph. D. (1973), vedoucí Katedry mezinárodních vztahů a evropských studií na Fakultě sociálních studií MU, odbornice na problematiku evropské integrace a členka Teamu Europe při Delegaci Evropské komise v České republice. Specializuje se na politický vývoj EU, na její institucionální otázky, teorie integračního procesu a otázky rozšiřování EU. Autorka, spoluautorka a editorka knižních monografií, studií a článků. Kontakt: pitrova@fss.muni.cz 